\title{
Modeling of air pollution related to the "V" natural gas deposit exploitation
}

\author{
Vitalii Kulynych, Michał Maruta \\ AGH University of Science and Technology, Faculty of Drilling, Oil and Gas, Department of Petroleum Engineering; \\ al. A. Mickiewicza 30,30-059 Krakow, Poland; e-mail: kulynych@agh.edu.pl
}

(C) 2016 Authors. This is an open access publication, which can be used, distributed and reproduced in any medium according vto the Creative Commons CC-BY 4.0 License requiring that the original work has been properly cited.

Exploitation of oil and gas deposits is often associated with a negative impact on the environment. This impact may be associated with the the activities on drilling rig, mine as well as situations in which there is a leakage or an eruption of a dangerous substance. The main sources of gaseous and particulate pollutants include the engines of drilling equipment and machines, boilers and transport used in the course of drilling, as well as the exploitation of the deposit. The risk of emissions of hazardous gases such as methane and hydrogen sulphide concentrations into the atmosphere occurs at the time of the eruption or leakage from the pipeline.

The paper presents an attempt to assess the impact of the technical work related to the exploitation of "V" gas deposit on the atmosphere including a variant in which there was a rapid leakage of the gas system. It discusses the type of pollutants emitted into the environment, and estimates the amount of emissions related to the equipment on the deposit (boilers, engines). The authors performed modelling of selected exhausted gases from the boiler spread into the air. The authors also performed simulations of the spread of hydrogen sulphide and natural gas, which leaked into the atmosphere by the eruption due to pipeline damage. Modelling was performed based on hazard modelling software ALOHA (Areal Locations of Hazardous Atmospheres) created by the US Environmental Protection Agency (EPA). The modelling made possible to determine the impact of air pollution zones and zones of dangers caused by hydrogen sulphide. It lso allowed to nominate the evacuation zones in case of an emergency situation.

Work was performed within the statutory research program of the Faculty of Drilling, Oil and Gas AGH UST no. 11.11.190.555.

\section{REFERENCES}

Borysiewicz M., 1996. Modelowanie wypływów i transportu uwolnień $w$ atmosferze substancji chemicznych. Modelowanie efektów fizycznych i skutków awarii chemicznych. Wydawnictwo AND, Warszawa.

Braddock J.D., Hart K. \& Hallman P.C., 1995. Developments in Regulation of Air Pollution from Oil and Gas Exploration and Production. [in:] SPE/EPA Exploration and Production Environmental Conference, 27-29 March, Houston, Texas, Society of Petroleum Engineers, 27-29.

Majder-Łopatka M. \& Salamonowicz Z., 2013. Prognozowanie zasięgu strefy zagrożenia toksycznego przy pomocy programu komputerowego ALOHA. Szkoła Główna Służby Pożarniczej, Zakład Ratownictwa Chemicznego, Warszawa.

Mazurczak M., Sówka I., Pachurka Ł. \& Sobczyński P., 2013. Charakterystyka emisji zanieczyszczeń do powietrza podczas rozpoznania złóż gazu ziemnego z łupków. [in:] Traczewska T.M. (red.), Interdyscyplinarne zagadnienia $w$ inżynierii i ochronie środowiska. Praca zbiorowa, 3, Oficyna Wydawnicza Politechniki Wrocławskiej, Wroclaw, 397-403.

Uliasz-Misiak B., 2015. Ryzyko środowiskowe związane z eksploatacją złóż węglowodorów zawierających siarkowodór. Rocznik Ochrona Środowiska, 17, 2, 1498-1511.

US Environmental Protection Agency, National Oceanic and Atmospheric Administration, 2007. The CAMEO Software System - ALOHA - user's manual. 